\title{
28 Research Square \\ The mechanism of jian-Gan-Xiao-Zhi decoction in IR adipocytes and its component analysis
}

\section{Research}

Keywords:

Posted Date: November 20th, 2020

DOl: https://doi.org/10.21203/rs.3.rs-18749/v4

License: (c) (1) This work is licensed under a Creative Commons Attribution 4.0 International License.

Read Full License 


\section{Abstract}

The authors have requested that this preprint be withdrawn due to author disagreement.

\section{Full Text}

The authors have withdrawn this preprint from Research Square. 